\title{
Pengembangan Model Economic Order Quantity Multi Item dengan Mempertimbangkan All Unit Discount dan Kendala Kapasitas
}

\section{The Development of Multi Item Economic Order Quantity Model by Considering All Unit Discount and Capacity Constraint}

\author{
Roland Y.H. Silitonga, Jonah Moses \\ Institut Teknologi Harapan Bangsa \\ E-mail: roland@ithb.ac.id, jonahwidodo@gmail.com
}

\begin{abstract}
Abstrak
Penelitian ini mengembangkan model persediaan economic order quantity untuk multi item product dengan mempertimbangkan all unit discount dan kendala kapasitas, yang umumnya merupakan permasalahan di usaha toko seperti mini market. Pengembangan model dilakukan dengan cara mengembangkan model persediaan economic order quantity multi item dengan mempertimbangkan all unit discount dari model terdahulu, dengan menambahkan faktor kendala kapasitas, menggunakan persamaan proporsi demand produk. Model yang telah dikembangkan diuji coba menggunakan beberapa skenario perubahan parameter model, untuk mengetahui tingkat sensitivitas model yang dikembangkan. Ditemukan bahwa perubahan parameter-parameter tidak sensitif terhadap total biaya persediaan maupun waktu pemesanan.
\end{abstract}

Kata kunci: economic order quantity, multi item, all unit discount, kendala kapasitas

\section{Abstract}

This research developed an economic order quantity inventory model for multi item products by considering all unit discounts and capacity constraint. Model development was done by using the previous multi item economic order quantity model which considering all unit discounts, then adding capacity constraints using the equation of product demand proportion. The model then tested using some parameters changing scenarios, to determine the level of sensitivity of the developed model. It was found that the parameters changes were not sensitive to the total inventory costs and ordering time.

Keywords: economic order quantity, multi item, all unit discount, capacity constraint.

\section{Pendahuluan}

Persediaan perlu dikelola sedemikian rupa agar perusahaan terhindar dari kemungkinan hilangnya penjualan atau biaya yang terlalu besar akibat penumpukan persediaan (Rambitan dkk, 2018). Dengan demikian kuantitas persediaan harus diatur sedemikian rupa sehingga kelancaran pemenuhan pemakai tetap terpenuhi, tetapi ongkos yang ditimbulkan haruslah sekecil mungkin (Bahagia, 2006). Pengaturan persediaan yang baik menjadi semakin penting saat ini, karena saluran distribusi penjualan dapat beragam. Bahkan manajemen persediaan bersama dengan pengaturan saluran distribusi, online maupun offline, dapat merupakan suatu strategi bisnis yang penting, seperti yang banyak terjadi pada perusahaan yang menjual secara online maupun offline (Silitonga dan Christina, 2019).

Pengembangan model yang dilakukan terkait dengan kasus nyata usaha produk konsumsi seperti pabrik makanan, atau pedagang produk konsumsi pada tingkat menengah dan kecil, terutama pada minimarket. Usaha jenis ini memiliki dua ciri khas. Pertama, ini merupakan faktor yang menjadi keunggulan sebuah minimarket dibanding toko tradisional, adalah kemampuan mendapatkan diskon dari pemasok. Hal ini akan memberikan dorongan untuk membeli lebih banyak persediaan, karena akan menurunkan biaya pembelian per unit produknya (Hunusalela, 2016). Kedua adalah permintaan produk-produknya dapat dikatakan bersifat stabil. Pada kondisi permintaan yang stabil dalam jangka panjang, ukuran pesanan akan berimplikasi pada rata-rata persediaan dan frekuensi pemesanannya. 
Model sederhana yang biasa digunakan untuk menentukan ukuran pesanan yang optimum adalah Economic Order Quantity (EOQ) (Pujawan dan Er, 2017). Model ini bersifat deterministik. Model ini cocok untuk jenis produk yang memiliki variansi relatif kecil, sehingga rata-rata persediaan dapat digunakan sebagai parameter yang dianggap konstan. Hal lain yang perlu diperhatikan adalah kendala kapasitas gudang karena gudang akan diisi oleh berbagai produk, padahal volumenya tidaklah besar, terutama pada usaha seperti toko kecil dan minimarket.

Pengembangan model persediaan telah banyak dilakukan, baik pada permintaan yang bersifat deterministik maupun probabilistik (Djunaidi dkk (2016), Limanjaya dan Silitonga (2018), Kusrini (2005), Utama (2016)). Djunaidi dkk (2005) membuat model economic order quantity (EOQ) multi item dengan mempertimbangkan faktor all unit discount. Kekurangan dalam penelitian ini yaitu tidak dimasukkannya faktor kendala kapasitas sehingga proses pengadaan barang bisa dilakukan pada jumlah berapapun. Koswara dan Lesmono (2018) menyatakan jumlah yang harus dipesan dalam usaha mendapatkan diskon tetap harus memperhatikan kapasitas gudang karena keterbatasan gudang menjadi penghalang jumlah barang yang harus diambil. Penelitian dengan menambahkan faktor kapasitas sudah dilakukan oleh Kusrini (2005) dengan mengembangkan model multi item dengan kendala kapasitas gudang. Fungsi pembatas kapasitas didekati dengan persamaan lagrange. Penelitian lain terkait dengan model persediaan dengan menambahkan faktor kapasitas juga dilakukan oleh Utama (2016) yang mengembangkan model persediaan untuk menentukan ukuran lot size pemesanan dengan menggunakan metode Wagner Within, dalam hal ini demand diasumsikan bersifat deterministik dinamis.

Penelitian ini mengembangkan model persediaan deterministik multi item dengan mempertimbangkan faktor all unit discount dan faktor kapasitas gudang. Pemaparan akan dibagi menjadi tiga. Pertama adalah deskripsi dan formulasi model yang dikembangkan. Kedua adalah uji coba model dengan beberapa kelompok parameter yang berbeda. Ketiga adalah kesimpulan dan saran yang didapat dari penelitian ini.

\section{Pengembangan Model}

\subsection{Deskripsi Model}

Model yang dikembangkan di dalam penelitian ini merupakan model persediaan economic order quantity dengan mempertimbangkan all unit discount dan kendala kapasitas. Dalam penelitian ini semua komponen model bersifat deterministik. Metode pencarian solusi pada model ini menggunakan pendekatan proporsi atau pendekatan heuristic, dengan cara mengembangkan persamaan proporsi dari fungsi kendala kapasitas.

\subsection{Notasi Model}

$\mathrm{D}_{\mathrm{i}} \quad$ : Permintaan barang item-i untuk suatu horison perencanaan (unit/tahun)

$\mathrm{C}_{\mathrm{ij}} \quad$ : Harga barang/unit untuk item-i pada interval diskon $\mathrm{j}$ harga (Rp/unit)

$\mathrm{H}_{\mathrm{i}}$ : Ongkos simpan barang item-i/unit/periode, karena pengaruh diskon maka $\mathrm{H}_{\mathrm{i}}=\mathrm{h}_{\mathrm{ij}} \cdot \mathrm{C}_{\mathrm{ij}}(\mathrm{Rp} / \mathrm{unit} /$ tahun $)$

$\mathrm{h}_{\mathrm{ij}}$. $\mathrm{C}_{\mathrm{ij}}$ : Persentase ongkos simpan barang/periode terhadap harga barang item-i pada interval diskon j harga (\%/tahun)

$\mathrm{S} \quad$ : Ongkos pesan untuk setiap kali pemesanan (Rp/pesan)

$\mathrm{Q}_{\mathrm{i}}^{*} \quad$ : Ukuran lot pemesanan ekonomis untuk barang item-i (unit)

$\mathrm{t}_{\mathrm{ij}}^{* *} \quad:$ Periode antar pemesanan (tahun)

$\mathrm{n} \quad$ : Jumlah item barang (unit)

$\mathrm{m}_{\mathrm{i}} \quad$ : Jumlah inventori rata-rata untuk item-i (unit)

$\mathrm{r} \quad$ : Jumlah interval diskon $\mathrm{j}$ harga (unit)

$\mathrm{N} \quad$ : Frekuensi pesan (pesan/tahun)

$\mathrm{QwP}_{\mathrm{i}}^{*} \quad$ : Persentase ukuran lot pemesanan untuk barang item-i (unit) dengan mempertimbangkan kapasitas

$\mathrm{Qw}_{\mathrm{i}}^{*} \quad$ : Kebutuhan luas tiap item-i (volume) 
$\mathrm{QW}_{\mathrm{i}}^{*} \quad$ : Volume tiap item-i setelah mempertimbangkan kapasitas gudang (volume)

$\mathrm{Qg}_{\mathrm{i}}^{*} \quad$ : Kuantitas pemesanan ekonomis untuk barang item-i (unit) setelah mempertimbangkan kapasitas

$\mathrm{w}_{\mathrm{i}} \quad$ : luas satuan item-i

W : Kapasitas gudang (volume)

$\mathrm{G} \quad$ : Periode antar pemesanan (tahun) setelah mempertimbangkan kapasitas

$\mathrm{C}_{\mathrm{ij}} \quad$ : harga per unit untuk item ke-i pada interval harga diskon $\mathrm{j}$.

$\mathrm{S}_{\mathrm{n}} \quad$ : biaya per pesan

$\mathrm{C}_{\mathrm{p}} \quad$ : Total biaya pembelian selama satu periode perencanaan $(\mathrm{Rp})$

$\mathrm{C}_{\mathrm{o}} \quad$ : Total biaya pemesanan selama satu periode perencanaan (Rp)

$\mathrm{C}_{\mathrm{h}} \quad$ : Total biaya penyimpanan selama satu periode perencanaan $(\mathrm{Rp})$

TIC : Total biaya persediaan selama satu periode perencanaan $(\mathrm{Rp})$

\subsection{Asumsi Model}

1. Semua produk dalam kondisi baik dan tidak memiliki kadaluarsa

2. Permintaan berlaju konstan dan diketahui dengan pasti, lead time juga diketahui dengan pasti

3. Tidak ada stockout maupun biaya stockout

4. Periode pemesanan untuk setiap item sama, dengan horison perencanaan satu tahun.

5. Item satu dengan yang lain bersifat independen.

6. Semua item yang dipesan akan datang pada satu titik waktu yang sama untuk setiap siklus.

7. Satuan kapasitas gudang konstan dan merupakan kelipatan dari satuan berbagai produk.

\subsection{Formulasi Model}

Komponen model terdiri atas biaya pembelian $\left(C_{p}\right)$, biaya pesan $\left(C_{o}\right)$ dan biaya simpan $\left(C_{h}\right)$ yang membentuk total biaya persediaan (TIC). Kebijakan pembelian barang pada penelitian ini mempertimbangkan biaya harga satuan karena adanya faktor all unit discount. Dalam penelitian ini discount yang diberikan akan bergantung pada besarnya kuantitas barang yang akan dipesan sehingga pada model ini akan mempertimbangkan optimal untuk memutuskan harga mana yang akan dipilih. Persamaan biaya pembelian pada penelitian ini adalah sebagai berikut:

$$
C_{p}=\sum_{i=1}^{n} C_{i j} D_{i}, j \in(1,2,3,4 \ldots r)
$$

Biaya pemesanan dalam penelitian ini dilakukan pada waktu yang sama untuk beberapa jenis barang atau biasa disebut dengan kebijakan pemesanan joint order. Persamaan biaya pemesanan adalah biaya yang muncul dari perkalian per pemesanan dengan banyaknya pemesanan yang dilakukan dalam satu horizon waktu perencanaan yang dapat dituliskan sebagai berikut:

$$
\mathrm{C}_{\mathrm{o}}=\sum \mathrm{N} \times \mathrm{S}_{\mathrm{n}}
$$

Jika periode pesan $(t)=\frac{1}{N}$ untuk semua item sama, maka $t_{1}=t_{2}=t_{3}=t_{n}$, sehingga biaya pemesanan menjadi :

$$
C_{o}=\frac{s}{t^{*}}
$$

Biaya penyimpanan didapatkan dari perkalian waktu antar pemesanan, demand, dan persentase harga biaya simpan per item dalam suatu horizon waktu perencanaan yang dapat dituliskan sebagai berikut:

$$
\text { Jika } N=\frac{D_{i}}{Q_{i}} \text { dan } t=\frac{1}{N} \rightarrow t=\frac{Q_{i}}{D_{i}} \text {, maka } Q_{i}=t^{*} \times D_{i}
$$

Sehingga biaya pesan menjadi :

$$
\mathrm{C}_{\mathrm{h}}=1 / 2 \sum_{\mathrm{i}=1}^{\mathrm{n}} \mathrm{t}^{*} \cdot \mathrm{D}_{\mathrm{i}} \cdot \mathrm{h}_{\mathrm{i}} \cdot \mathrm{C}_{\mathrm{ij}}, \mathrm{j} \in(1,2,3, \ldots . \mathrm{r})
$$


Biaya persediaan total didapatkan dengan mensubstitusikan persamaan yang sudah dijabarkan sebelumnya yaitu persamaan (1), (3), dan (5) ke dalam persamaan TIC $=C_{o}+C_{p}+C_{h}$ sebagai berikut:

$$
\text { TIC }=\sum_{i=1}^{n} C_{i j} \cdot D_{i}+\frac{S}{t^{*}}+\frac{1}{2} \sum_{i=1}^{n} t^{*} \cdot D_{i} \cdot h_{i} \cdot C_{i j}, j \in(1,2,3, \ldots . r)
$$

Setelah mendapatkan formula biaya persediaan total maka langkah selanjutnya adalah menurunkan persamaan TIC untuk mendapatkan waktu antar pemesanan optimal dengan cara diturunkan terhadap $\mathrm{t}^{*}$ atau dapat ditulis sebagai $\frac{\partial T I C}{\partial \mathrm{t}}=0$. Persamaan untuk mencari nilai $\mathrm{t}^{*}$ dapat dilihat pada persamaan berikut:

$$
t_{i j}^{*}=\sqrt{\frac{2 s}{\sum_{i=1}^{n} D_{i} x h_{i} \times C_{i j}}}, j \in(1,2,3, \ldots r)
$$

Algoritme pengerjaan model adalah sebagai berikut:

1. Hitung jarak pesan optimal $\left(t^{*}\right)$ untuk masing - masing item-i pada interval diskon harga $j$ $\left(t_{i j}^{*}\right)$ pada harga satuan terkecil terlebih dahulu.

2. Selanjutnya hitung kuantitas pesan optimal untuk item- $i\left(Q_{i}^{*}\right)$ untuk permintaan item- $i\left(D_{i}\right)$.

3. Tentukan apakah $Q_{i}^{*}$ yang telah dihitung berada pada interval diskon harga $j$ atau di luar interval diskon harga $j .\left(Q_{i}^{*}\right)$ dikatakan valid apabila $Q_{i}^{*}$ berada di dalam interval diskon harga $j$. Jika $Q_{i}^{*}$ belum masuk dalam rentang harga satuan yang ada maka lakukan literasi kembali.

4. Carilah kebutuhan luas tiap item dengan menggunakan persamaan berikut:

$\mathrm{Qw}_{\mathrm{i}}^{*}=\mathrm{Q}_{\mathrm{i}}^{*} \times \mathrm{w}_{\mathrm{i}}$

Jika $\sum_{\mathrm{i}=1}^{\mathrm{n}} \mathrm{Q} \mathrm{w}_{\mathrm{i}}^{*}>\mathrm{W}$ maka lanjutkan perhitungan ke langkah 5 .

5. Cari persentase tiap $\mathrm{QwP}_{\mathrm{i}}^{*}$ dengan persamaan berikut:

$\mathrm{QwP}_{\mathrm{i}}^{*}=\frac{\mathrm{Qw}_{\mathrm{i}}^{*}}{\sum_{\mathrm{i}=1}^{\mathrm{n}} \mathrm{Qw}_{\mathrm{i}}^{*}}$

6. Lakukan perkalian masing - masing $Q w P_{i}^{*}$ dengan kapasitas yang tersedia saat ini untuk mendapatkan nilai $\mathrm{QW}_{\mathrm{i}}^{*}$ dengan persamaan berikut:

$\mathrm{QW}_{\mathrm{i}}^{*}=\mathrm{QwP}_{\mathrm{i}}^{*} \mathrm{xW}$

7. Karena satuan barang masih dalam bentuk volume maka harus diubah kembali dalam bentuk unit untuk mendapatkan nilai $\mathrm{Qg}_{\mathrm{i}}^{* *}$ menggunakan persamaan:

$\mathrm{Qg}_{\mathrm{i}}^{*}=\frac{\mathrm{QW}_{\mathrm{i}}^{*}}{\mathrm{w}_{\mathrm{i}}}$

Setelah menghitung $\operatorname{Qg}_{\mathrm{i}}^{*}$ langkah berikutnya menyesuaikan nilai $\mathrm{Qg}_{\mathrm{i}}^{*}$ dengan interval diskon

8. Kemudian cari kembali periode antar pemesanan setelah mempertimbangkan kapasitas dengan persamaan berikut:

$\mathrm{G}=\frac{\sum_{\mathrm{i}=1}^{\mathrm{n}} \mathrm{Qg}_{\mathrm{i}}^{*}}{\sum_{\mathrm{i}=1}^{\mathrm{n}} \mathrm{D}_{\mathrm{i}}}$

9. Kemudian hitung biaya total persediaan (TIC) untuk kuantitas pesan optimal untuk item- $i$ yang berada di dalam interval diskon harga $j\left(Q g_{i}^{*}\right)$ menggunakan nilai waktu antar pemesanan setelah mempertimbangkan kapasitas $(G)$

\subsection{Contoh Numerik}

Model yang dikembangkan diverifikasi dengan memastikan setiap persamaan yang ada memiliki dimensi yang sama pada sisi kiri dan kanan tanda sama dengan. Validasi dilakukan dengan melihat perilaku model, yaitu apakah output yang dihasilkan menggambarkan kondisi nyata, termasuk di dalamnya melihat sensitivitas output akibat perubahan input. Untuk itu perlu dilakukan uji coba dengan contoh numerik. 
Diketahui data sebagai berikut:

Tabel 1. Data Produk

\begin{tabular}{|c|c|c|c|}
\hline & Produk 1 & Produk 2 & Produk 3 \\
\hline $\mathrm{D}_{\mathrm{i}}$ & 55.500 & 40.000 & 80.000 \\
\hline $\mathrm{h}_{\mathrm{i}}$ & 0,001 & 0,015 & 0,01 \\
\hline $\mathrm{C}_{\mathrm{i}}$ & 13.000 untuk $\mathrm{Q}<9.000$ & 16.000 untuk $\mathrm{Q}<6.500$ & 9.000 untuk $\mathrm{Q}<13.000$ \\
& 12.000 untuk $\mathrm{Q} \geq 9.000$ & 15.000 untuk $\mathrm{Q} \geq 6.500$ & 8.000 untuk $\mathrm{Q} \geq 13.000$ \\
& 11.000 untuk $\mathrm{Q} \geq 15.000$ & 13.000 untuk $\mathrm{Q} \geq 12.000$ & 7.000 untuk $\mathrm{Q} \geq 21.000$ \\
\hline$w_{i}$ & 2,5 & 2 & 3 \\
\hline $\mathrm{W}$ & \multicolumn{3}{|c|}{50.000} \\
\hline $\mathrm{S}$ & \multicolumn{3}{|c|}{235.000} \\
\hline
\end{tabular}

Waktu pesan optimal ( $t_{i j}^{*}$ ) dapat dihitung menggunakan persamaan (7) dengan menggunakan harga satuan paling kecil terlebih dahulu.

$$
\begin{aligned}
& \mathrm{t}_{\mathrm{ij}}^{*}=\sqrt{\frac{2 \mathrm{~s}}{\sum_{\mathrm{i}=1}^{\mathrm{n}} \mathrm{D}_{\mathrm{i}} \times \mathrm{h}_{\mathrm{i}} \times \mathrm{C}_{\mathrm{ij}}}} \\
& \mathrm{t}_{132333}^{*}=\sqrt{\frac{2 \times 235.000}{(55.500 \times 0,001 \times 11.000)+(40.000 \times 0,015 \times 13.000)+(80.000 \times 0,01 \times 7.000)}} \\
& \mathrm{t}_{132333}^{*}=0,183 / \text { tahun }
\end{aligned}
$$

Setelah menghitung waktu antar siklus optimal maka langkah selanjutnya adalah mencari jumlah barang yang harus dipesan per 1 kali siklus pemesanan (Qi*) dengan menggunakan persamaan (4). $Q_{i}^{*}=t_{i j}^{*} \times D_{i}$

a. Untuk $\mathrm{D}_{1}=55.500$ unit/tahun

$Q_{1}^{*}=0,183 \times 55.500=10.165,18$

Tidak berada pada interval diskon harga $\mathrm{Q} \geq 15.000$ maka hitung menggunakan interval diskon harga yang lain

b. Untuk $\mathrm{D}_{2}=40.000$ unit/tahun

$\mathrm{Q}_{2}^{*}=0,183 \times 40.000=7.326,25$

Tidak berada pada interval diskon harga $\mathrm{Q} \geq 12.000$ maka hitung menggunakan interval diskon harga yang lain

c. Untuk $\mathrm{D}_{3}=80.000$ unit/tahun

$\mathrm{Q}_{3}^{*}=0,183 \times 80.000=14.652,51$

Tidak berada pada interval diskon harga $\mathrm{Q} \geq 21.000$ maka hitung menggunakan interval diskon harga yang lain

Karena hasil perhitungan tidak berada pada interval diskon harga maka hitung kembali $t_{i j}^{*}$ dengan interval diskon harga yang lainnya, dan kemudian hitung kembali waktu antar siklus $\left(t_{i j}^{*}\right)$ untuk satuan harga yang berbeda menggunakan persamaan (7)

$$
\begin{aligned}
& \mathrm{t}_{\mathrm{ij}}^{*}=\sqrt{\frac{2 \mathrm{~s}}{\sum_{\mathrm{i}=1}^{\mathrm{n}} \mathrm{D}_{\mathrm{i}} \times \mathrm{h}_{\mathrm{i}} \times \mathrm{C}_{\mathrm{ij}}}} \\
& \mathrm{t}_{132333}^{*}=\sqrt{\frac{2 \times 235.000}{(55.500 \times 0,001 \times 12.000)+(40.000 \times 0,015 \times 15.000)+(80.000 \times 0,01 \times 8.000)}} \\
& \mathrm{t}_{132333}^{*}=0,171 / \text { tahun }
\end{aligned}
$$

Setelah menghitung waktu antar siklus optimal maka langkah selanjutnya adalah mencari jumlah barang yang harus dipesan per 1 kali siklus pemesanan (Qi*) dengan menggunakan persamaan (4). $Q_{i}^{*}=t_{i j}^{*} \times D_{i}$ 
a. Untuk $\mathrm{D}_{1}=55.500$ unit/tahun

$\mathrm{Q}_{1}^{*}=0,171 \times 55.500=9.492,66$

Berada pada interval diskon harga $\mathrm{Q} \geq 9.000$

b. Untuk $\mathrm{D}_{2}=40.000$ unit/tahun

$\mathrm{Q}_{2}^{*}=0,171 \times 40.000=6.841,55$

Berada pada interval diskon harga $\mathrm{Q} \geq 6.500$

c. Untuk $\mathrm{D}_{3}=80.000$ unit/tahun

$\mathrm{Q}_{3}^{*}=0,171 \times 80.000=13.683,11$

Tidak berada pada interval diskon harga $\mathrm{Q} \geq 13.000$

Karena hasil perhitungan berada pada interval diskon harga maka lanjutkan hasil perhitungan dengan mempertimbangkan kapasitas gudang. Perhitungan jumlah barang yang harus dipesan menggunakan persamaan (8), (9), (10), dan (11)

Perhitungan kebutuhan luas masing - masing item:

$\mathrm{Qw}_{\mathrm{i}}^{*}=\mathrm{Q}_{\mathrm{i}}^{*} \times \mathrm{w}_{\mathrm{i}}$

a. Untuk $Q_{1}^{*}=9.492,66$

$\mathrm{Qw}_{1}^{*}=9.492,66 \times 2,5=23.731,65 \mathrm{~m}^{3}$

b. Untuk $Q_{2}^{*}=6.841,55$

$\mathrm{Qw}_{2}^{*}=6.841,55 \times 2=13.683,11 \mathrm{~m}^{3}$

c. Untuk $Q_{3}^{*}=13.683,11$

$\mathrm{Qw}_{3}^{*}=13.683,11 \times 3=41.049,35 \mathrm{~m}^{3}$

Lakukan perhitungan jumlah kebutuhan luas seluruh item

$\sum_{\mathrm{i}=1}^{\mathrm{n}} \mathrm{Qw}_{\mathrm{i}}^{*}>\mathrm{W}$

$\mathrm{Qw}_{1}^{*}+\mathrm{Qw}_{2}^{*}+\mathrm{Qw}_{3}^{*}>\mathrm{W}$

$23.731,65+13.683,11+41.049,35>50.000$

$78.464,12>50.000$

Karena kebutuhan luas item lebih besar dari kapasitas maka jumlah $Q_{i}^{*}$ harus dikurangi yang berdampak pada semakin seringnya melakukan pemesanan.

Perhitungan persentase kebutuhan luas masing - masing item

$\mathrm{QwP}_{\mathrm{i}}^{*}=\frac{\mathrm{Qw}_{\mathrm{i}}^{*}}{\sum_{\mathrm{i}=1}^{\mathrm{n}} \mathrm{Qw}_{\mathrm{i}}^{*}}$

a. Untuk $\mathrm{Qw}_{1}^{*}=23.731,65$

$\mathrm{QwP}_{\mathrm{i}}^{*}=\frac{23.731,65}{78.464,12}=0,302$

b. Untuk $\mathrm{Qw}_{2}^{*}=13.683,11$

$\mathrm{QwP}_{2}^{*}=\frac{13.683,11}{78.464,12}=0,174$

c. Untuk $\mathrm{Qw}_{3}^{*}=41.049,35$

$$
\mathrm{QwP}_{3}^{*}=\frac{41.049,35}{78.464,12}=0,523
$$

Perhitungan jumlah volume tiap item dengan mempertimbangkan volume kapasitas gudang:

$\mathrm{QW}_{\mathrm{i}}^{*}=\mathrm{QwP}_{\mathrm{i}}^{*} \mathrm{xW}$
a. Untuk $\mathrm{QwP}_{1}^{*}=0,302$
$\mathrm{QW}_{1}^{*}=0,302 \times 50.000=15.122,61$
b. Untuk $\mathrm{QwP}_{2}^{*}=0,174$
$\mathrm{QW}_{2}^{*}=0,174 \times 50.000=8.719,34$
c. Untuk $\mathrm{QwP}_{3}^{*}=0,523$
$\mathrm{QW}_{2}^{*}=0,523 \times 50.000=26.158,03$

Satuan barang yang masih berbentuk volume harus dikembalikan dalam satuan unit untuk dapat memperhitungkan total biaya ongkos inventorinya: 
$\mathrm{Qg}_{\mathrm{i}}^{*}=\frac{\mathrm{QW}_{\mathrm{i}}^{*}}{\mathrm{w}}$

1. Untuk $\mathrm{QW}_{1}^{*}=15.122,61$

$\mathrm{Qg}_{1}^{*}=\frac{15.122,61}{2,5}=6.049,04$

$\mathrm{Qg}_{1}^{* *}$ masuk pada interval diskon dengan harga satuan 13.000

2. Untuk $\mathrm{QW}_{2}^{*}=8.719,34$

$$
\mathrm{Qg}_{2}^{*}=\frac{8.719,34}{2}=4.359,67
$$

$\mathrm{Qg}_{2}^{* *}$ masuk pada interval diskon dengan harga satuan 16.000

3. Untuk $\mathrm{QW}_{3}^{*}=26.158,03$

$\mathrm{Qg}_{3}^{*}=\frac{26.158,03}{2}=8.719,34$

$\mathrm{Qg}_{3}^{*}$ masuk pada interval diskon dengan harga satuan 9.000

Perhitungan waktu antar siklus dengan mempertimbangkan kendala kapasitas berdasarkan persamaan 12:

$$
\begin{aligned}
G & =\frac{\sum_{i=1}^{n} Q_{i}^{*}}{\sum_{i=1}^{n} D_{i}} \\
G & =\frac{6.049,04+4.359,67+8.719,34}{55.000+40.000+80.000}=0,108 / \text { tahun }
\end{aligned}
$$

Perhitungan biaya pembelian:

$\mathrm{C}_{\mathrm{p}}=$ Rp. $721.500 .000+$ Rp. $640.000 .000+$ Rp. 720.000 .000

$\mathrm{C}_{\mathrm{p}}=$ Rp. 2.081.500.000

Perhitungan biaya pemesanan:

$\mathrm{C}_{\mathrm{o}}=\frac{235.000}{0,108}$

$\mathrm{C}_{\mathrm{o}}=$ Rp. 2.156 .125

Perhitungan biaya penyimpanan:

$$
\begin{aligned}
& C_{h}=\text { Rp. 39.319+Rp. } 523.161+\text { Rp. } 392.371 \\
& C_{h}=\text { Rp. } 954.850
\end{aligned}
$$

Perhitungan total biaya Persediaan:

TIC $=$ Rp. $2.081 .500 .000+$ Rp. $2.156 .125+$ Rp. 954.850

$\mathrm{TIC}=\mathrm{Rp} .2 .084 .610 .97$

\section{Analisis}

Analisis sensitivitas dilakukan dengan mengubah nilai parameter kapasitas gudang, harga satuan, biaya simpan dan biaya pesan. Perubahan parameter dimulai dengan $10 \%$, di mana jika terdapat

\begin{tabular}{|c|c|c|c|c|c|c|c|c|c|c|}
\hline \multicolumn{11}{|c|}{ Perubahan Waktu Pemesanan (Per Tahun) } \\
\hline Elemen Analisis & $-10 \%$ & $-9 \%$ & $-8 \%$ & $-7 \%$ & $-6 \%$ & $-5 \%$ & $-4 \%$ & $-3 \%$ & $-2 \%$ & $-1 \%$ \\
\hline Harga Satuan & 0,1090 & 0,1090 & 0,1090 & 0,1090 & 0,1090 & 0,1090 & 0,1090 & 0,1090 & 0,1090 & 0,1090 \\
\hline Biaya Pesan & 0,1090 & 0,1090 & 0,1090 & 0,1090 & 0,1090 & 0,1090 & 0,1090 & 0,1090 & 0,1090 & 0,1090 \\
\hline Elemen Analisis & $10 \%$ & $9 \%$ & $8 \%$ & $7 \%$ & $6 \%$ & $\mathbf{5} \%$ & $4 \%$ & $3 \%$ & $2 \%$ & $1 \%$ \\
\hline Kapasitas Gudang & 0,1199 & 0,1188 & 0,1177 & 0,1166 & 0,1155 & 0,1144 & 0,1134 & 0,1123 & 0,1112 & 0,1101 \\
\hline Biaya Pesan & 0,1090 & 0,1090 & 0,1090 & 0,1090 & 0,1090 & 0,1090 & 0,1090 & 0,1090 & 0,1090 & 0,1090 \\
\hline
\end{tabular}
perubahan output yang sangat besar, dapat diperkecil sesuai kebutuhan. Hasil perhitungan perubahan parameter dari $-10 \%$ sampai dengan $+10 \%$ terhadap persentase perubahan biaya total dapat dilihat pada tabel 2.

Tabel 2. Analisis sensitivitas Biaya Total terhadap perubahan parameter 
Terlihat bahwa selain perubahan yang signifikan secara proporsional yang diakibatkan perubahan harga satuan, biaya total tidaklah sensitif terhadap perubahan parameter-parameter yang lain. Hal ini terjadi karena pengaruh kapasitas gudang yang menyebabkan kuantitas produk yang dibeli tidak dapat melebihi sejumlah tertentu produk, di samping proporsi pengaruh ketiga parameter lain yang tidak besar. Untuk itu perubahan parameter dengan persentase $10 \%$ sudah dianggap cukup menggambarkan perilaku sistem, tidak perlu diperkecil lebih lanjut.

Perbandingan struktur model matematika antara model Djunaidi (2005) Setiawan (2012) dan model yang dikembangkan dapat dilihat pada tabel 3 .

Tabel 3 Perbandingan struktur model dengan penelititan terdahulu

\begin{tabular}{|c|c|c|c|}
\hline Komponen Model & Model Persediaan I (Diunaidi, 2005) & Model Persediaan 2 (Setiawan, 2012) & Model Persediaan 3 (Pengembangan) \\
\hline Biaya Pembelian & $\sum_{i=1}^{n} C C_{i j} \underset{i}{D} j \in(1,2,3,4 \ldots r)$ & $\sum_{j=1}^{n} C_{i} \times D_{i}$ & $\sum_{i=1}^{n} C C_{i j} \underline{D}, j \in(1,2,3,4 \ldots r)$ \\
\hline Biava Pemesanan & $\frac{s}{t^{*}}$ & $\sum_{j=1}^{n} \underline{A}_{i} \underline{\underline{D}}_{i}$ & $\frac{s}{t^{*}}$ \\
\hline Biava Penvimpanan & $\begin{array}{l}1 / 2, \sum_{i=1}^{n} t^{*} \cdot D_{i} \cdot h_{i} \cdot C_{i j}, j \in \\
(1,2,3, \ldots . . . r)\end{array}$ & 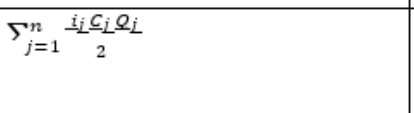 & $\begin{array}{l}1 / 2, \sum_{i=1}^{n} t^{*} \cdot D_{i} \cdot h_{i} \cdot C_{i j}, j \in \\
(1,2,3, \ldots . \ldots r)\end{array}$ \\
\hline t Optimal & 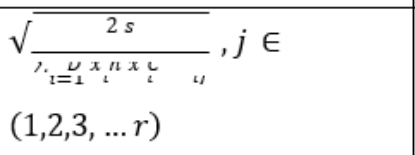 & & $\begin{array}{l}\sqrt{\frac{2 s}{h_{l=1}^{\nu} x_{l} n x_{l}} u}, j \in \\
(1,2,3, \ldots r)\end{array}$ \\
\hline Q Optimal & $t^{*} x D_{i}$ & & $t^{*} x D_{i}$ \\
\hline Q Kapasitas & & 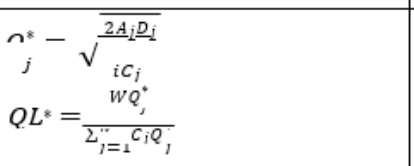 & $\begin{array}{l}Q W_{t}^{*}=Q w P_{t}^{*} x W \\
Q g_{i}^{*}=\underline{\underline{r}}^{*} \underline{\underline{i}}^{*} \\
w\end{array}$ \\
\hline t Kapasitas & & & $\sum_{i=1}^{\sum_{i=1}^{n} Q D_{i}^{n}} Q g_{L}^{*}$ \\
\hline
\end{tabular}

Hasil perbandingan model pada tabel 3 menunjukkan adanya perbedaan antara model persediaan 2 dengan model persediaan 1 dan model persediaan 3. Perbedaan persamaan biaya pembelian dalam model persediaan 2 disebabkan oleh tidak dipertimbangkannya faktor diskon didalam perhitungannya sehingga hanya menggunakan satu jenis harga satuan. Persamaan biaya pemesanan dan biaya pembelian pada model persediaan 2 tidak menggunakan kebijakan joint order (waktu kedatangan barang sama) namun model persediaan 1 dan model persediaan 3 menggunakan kebijakan. Persamaan perhitungan Q kapasitas pada model persediaan 2 menggunakan metode lagrange sedangkan model persediaan 3 menggunakan pendekatan proporsi permintaan berdasarkan persamaan pembatas yang dibuat pada model persediaan 2 .

Hal penting yang perlu dilihat dalam pengembangan model ini adalah dengan adanya perubahan kuantitas untuk mengikuti kapasitas gudang secara proporsional pada seluruh item produk, maka model yang dikembangkan ini tidak mendapatkan solusi optimum, yang menghasilkan biaya minimum. Di sisi lain, jika jumlah item banyak, dengan harga rendah dan bukanlah kategori penting (A) secara penyerapan modal, maka penerapan jumlah proporsional pada kuantitas barang untuk mengikuti kapasitas gudang, adalah model yang relevan dan mudah diterapkan di lapangan. Implikasi manajerial yang perlu diperhatikan adalah pendataan produk kategori $\mathrm{C}$ yang merupakan aplikasi model ini, termasuk di dalamnya adalah memastikan kestabilan permintaan dari produkproduk tersebut. Selain itu, pengelompokan produk dari pemasok yang sama dapat dijadikan dasar untuk pengelompokan multi-item.

\section{Kesimpulan dan Arah Penelitian Lanjutan}

Berdasarkan hasil uji coba dan analisis hasil dapat diambil beberapa kesimpulan sebagai berikut. Pertama, hasil dari model yang dikembangkan tidak memiliki hasil optimal seperti metode analitis, namun model yang dikembangkan mempunyai kelebihan seperti proses pengerjaan yang lebih mudah dipahami oleh pekerja lapangan dan waktu pencarian solusi yang lebih cepat. Kedua, 
berdasarkan hasil analisis sensitivitas, waktu pemesanan dan total biaya persediaan tidak sensitif terhadap perubahan nilai parameter-parameter. Hal ini menunjukkan bahwa model yang dikembangkan cukup kokoh. Ketiga, model yang dikembangkan dalam penelitian ini lebih baik diterapkan pada kondisi di mana terdapat jumlah item banyak, dengan harga rendah dan bukanlah kategori penting (A) secara penyerapan modal.

Terdapat saran untuk penelitian lanjutan yaitu mempertimbangkan beberapa produk yang lebih penting dari yang lain, sehingga proporsi dapat merupakan fungsi dari permintaan. Selain itu model dapat juga mempertimbangkan kasus multi item di mana terdapat produk yang memiliki waktu kadaluwarsa.

\section{Daftar Pustaka}

Bahagia, S. N. (2006), Sistem Inventori, Penerbit ITB, Bandung.

Djunaidi, M., Nandiroh, S. dan Marzuki, I. O. (2005), Pengaruh Perencanaan Pembelian Bahan Baku dengan Model EOQ Multi Item dengan All Unit Discount, Jurnal ilmiah Teknik Industri, Vol. 4 No. 2, pp. 86 - 94.

Hunusalela. Z. F. (2016), Model Inventory Perishable Material dengan Mempertimbangkan Faktor Kapasitas Gudang Penyimpanan Bahan Baku PT. So Good Food Manufacturing, Jurnal Teknik Industri, Universitas Indraprasta PGRI.

Koswara, H. dan Lesmono, D. (2018), Penentuan Waktu antar Pemesanan Optimal untuk Model Persediaan Probabilistik Multi Item dengan All-Units Discount dan Kendala Kapasitas Gudang, Performa, Vol. 17 No. 1, 1-6

Kusrini, E. (2005), Sistem Persediaan Multi Item dengan Kendala Investasi dan Luas Gudang, Jurnal Teknologi Industri, Vol. 10 No. 2, pp. 95-103.

Limanjaya, B. dan Silitonga, R. Y. H. (2018), Development of Multi Item Probabilistic Inventory Model by Considering Perishable and Purchase Bonus Factors, Jurnal Telematika, Vol. Edisi Khusus IESC 2018, pp. 54-59.

Pujawan, I. N. P. dan Er, M. (2017), Supply Chain Management, Edisi 3, Penerbit Andi, Yogyakarta.

Rambitan, B. F. dan Sumarauw, J. S. B. dan Jan, A. H. (2018), Analisis Penerapan Manajemen Persediaan Pada CV. Indospice Manado, Jurnal EMBA, Vol. 6 No. 3, pp. 1448-1457.

Setiawan, A. dan Hayati, E.N. (2012), Pengendalian Persediaan Barang Jadi Multi Item dengan Metode Lagrange Multiplier, Proceeding Seminar Nasional Sains dan Teknologi 3, Semarang.

Silitonga, R. Y. H. dan Christina, N. (2019), Price and Inventory Strategy Model in a Price Sensitive Dual Channel Supply Chain Structure Considering Product Substitution, IOP Conference Series: Material Science and Engineering, Vol. 703 No. 1.

Utama, D. M. (2016), Penentuan Lot Size Pemesanan Bahan Baku dengan Batasan Kapasitas Gudang, Jurnal Ilmiah Teknik Industri, Vol. 15 No. 1, pp. 64-68. 